\title{
Distance learning, technological devices, lifestyle and behavior of children and their family during the COVID-19 lockdown in Lombardy: a survey
}

\author{
Marina Picca ${ }^{1}$, Paola Manzoni ${ }^{1}$, Gregorio Paolo Milani ${ }^{2,3^{*}}$ (D, Susanna Mantovani ${ }^{4}$, Claudio Cravidi ${ }^{1}$, Danila Mariani ${ }^{1}$,
} Angela Mezzopane ${ }^{1}$, Roberto Marinello ${ }^{1}$, Chiara Bove ${ }^{5}$, Paolo Ferri ${ }^{5}$, Marina Macchi ${ }^{2,3}$ and Carlo Agostoni ${ }^{2,3}$

\begin{abstract}
Background: The COVID-19 pandemic and the subsequent national lockdowns, school closures and distance learning may have had both negative and positive effects on physical and mental health of children.

Methods: A cross-sectional study was conducted on a large group of children between 1 and 10 years old in Lombardy, Italy $(n=3392)$. Their parents filled in a survey answering single or multiple-choice questions about their offspring's behavior changes (including sleep, dietary habits, emotional disturbances), relationship with siblings, parents and peers, the use of digital technologies, and distance learning experience during the lockdown.

Results: Parents reported lifestyles and emotional alterations during the lockdown. The modifications of family relationships, parents' remote working, and screen time were associated with sleep, emotional and behavioral modifications. Distance learning was overall considered adequate.

Conclusions: This study reported the most updated data on the effects of COVID-19 pandemic lockdown on children between 1 and 10 years of age in a large sample of Italian schoolchildren. The results of this study point out that pediatricians and authorities should support relationships within families during the COVID-19 pandemic. Parents' remote working might play an important role for this purpose.
\end{abstract}

Keywords: COVID-19, Remote working, Distance learning, SARS-CoV-2, Consequences

\section{Background}

The COVID-19 pandemic had an impact on everyday life, creating a prolonged period of uncertainty for everyone, including children. To reduce the virus' spread, several measures have been implemented, including national lockdowns and school closures with subsequent distance learning (DL) through digital classes. According

\footnotetext{
* Correspondence: milani.gregoriop@gmail.com

2Fondazione IRCCS Ca' Granda - Ospedale Maggiore Policlinico, Pediatric Area, Via della Commenda 9, 20121 Milan, Italy

${ }^{3}$ Department of Clinical Sciences and Community Health, University of Milan, Milan, Italy

Full list of author information is available at the end of the article
}

to available evidence, these restrictions have led to temporary social isolation and consequent reduction of cognitive and physical stimuli, with potential negative effects on physical and mental health of children [1-5]. Moreover, it is known that isolation tends to be correlated with higher screen exposure, reduced physical activity and movement, worse dietary habits and sleep disturbances [4-11].

However, only a few studies on the topic are available in the literature and they mainly focused on the negative effects of lockdown on behavioral and psychological

(c) The Author(s). 2021 Open Access This article is licensed under a Creative Commons Attribution 4.0 International License, which permits use, sharing, adaptation, distribution and reproduction in any medium or format, as long as you give appropriate credit to the original author(s) and the source, provide a link to the Creative Commons licence, and indicate if changes were made. The images or other third party material in this article are included in the article's Creative Commons licence, unless indicated otherwise in a credit line to the material. If material is not included in the article's Creative Commons licence and your intended use is not permitted by statutory regulation or exceeds the permitted use, you will need to obtain permission directly from the copyright holder. To view a copy of this licence, visit http://creativecommons.org/licenses/by/4.0/. The Creative Commons Public Domain Dedication waiver (http://creativecommons.org/publicdomain/zero/1.0/) applies to the data made available in this article, unless otherwise stated in a credit line to the data. 
functions, such as lower social cognition and emotional development and socio-affective problems [5-9, 12].

The present study aimed to investigate the effects of the COVID-19 lockdown on pre and school-age children in Lombardy (the region with the major burden of COVID-19 in Italy) regarding behaviors and daily life, with special emphasis on distance learning and the use of digital device and.

\section{Methods}

A cross-sectional study ("Bambini e lockdown: la parola ai genitori" - "Children and lockdown: the voices of the parents") was performed between July and August 2020 in Lombardy, Italy, shortly after the spring lockdown period ended.

Data from 3392 children between 1 and 10 years old were collected using an anonymous on-line survey distributed by the SICuPP network ("Società Italiana delle Cure Primarie Pediatriche" - "Italian Society of Primary Care") Lombardy, in collaboration with the University of Milano Bicocca and "Bambini Bicocca" ("Children Bicocca"). Demographic information on the children, including, among other items, the age, gender and number of siblings, was collected. Characteristics of the house, number and type of technological devices available in the family were also investigated. Moreover, parents filled-in single or multiple-choice questions about their offspring's behavior regarding sleep, nutrition, emotional state, relationship with siblings, parents, and peers, the use of digital technologies, and DL experience.

Regarding their child's daily habits, parents were asked about possible changes during lockdown in the relationships between children and parents or siblings ("positive", "negative", "no relevant change"), sleep ("reduced hours of sleep", "night awakenings", "nightmares", "daytime sleepiness", "difficulty falling asleep") and nutritional habits including "modification of appetite" (decreased, not modified, increased) and "consumption of snacks between meals" (decreased, not modified, increased). The occurrence of irritability/tantrums (for children 1-5 years old) or irritability /rage (for children 6-10 years old), attention disturbances (e.g. reduced ability to focus on a task) of children were also asked.

The collected information was used in an anonymous and aggregate form, in compliance with the EU General Data Protection Regulation n. 679/2016 (D.gls. n.196/ 2003 modified by D.gls. n. 101 del 10.08.2018).

Data are presented as frequency and percentages. The possible relationship between the presence of sleep, attention and mood disturbances (for younger children) or irritability (for older children), (dependent variables), and possibly associated factors were explored by multiple logistic regression analysis. The following independent variables were considered: age, gender, number
Table 1 Data on sleep, nutrition, and moods disturbances in YC (1-5 years of age) and OC (6-10 years of age) group (13)

\begin{tabular}{lll}
\hline & $\begin{array}{l}\text { Children } \\
1-5 \text { years } \\
\%^{\text {a }}\end{array}$ & $\begin{array}{l}\text { Children } \\
6-10 \text { years } \\
\%^{\text {a }}\end{array}$ \\
\hline Sleep disturbances & 40 & 48 \\
Dietary habits modifications & 40 & 48 \\
Mood changes & 61 & 72 \\
Irritability/tantrums (YC) - & 81 & 68 \\
Irritability/rage (OC) & & \\
\hline
\end{tabular}

a Percentages refer to the number of parents who reported a change in their child during the lockdown $(N=1142$ in children $1-5$ years; $N=1177$ in

children 6-10 years)

of siblings, modifications of relationship between parents or between parents and the child during the lockdown, parents' remote working, presence of an external space in the house, the use of digital devices $(>4 \mathrm{~h}$ /day in older and $>2 \mathrm{~h}$ /day in younger children), time spent for TV watching. Akaike information criterion was used to select the most statistically relevant variables.

The study was conducted in compliance with all ethical research standards. All parents provide their consent to participate. The entire research process was monitored and approved by the University of Milano Bicocca.

\section{Results}

Data were collected for 3392 children of whom 1688 (49.8\%) between 1 and 5 years old (YC) and 1704 (50.2\%) between 6 and 10 (OC). Males were 51 and 53\% in $\mathrm{YC}$ and $\mathrm{OC}$ group, respectively. On average, there were two children per family.

Data about daily life and emotion items were partially previously published [13] and the most interesting data are summarized in Table 1.

Many electronic devices were present in each family: one or often two computers, two or more mobile phones and printers. In the OC group, $64 \%$ had access to parents' devices, $36 \%$ used a personal device for DL, $89 \%$ of mothers followed their children during DL. Regarding teaching methods, the majority (72\%) of teachers used live video-lessons, while a smaller percentage used

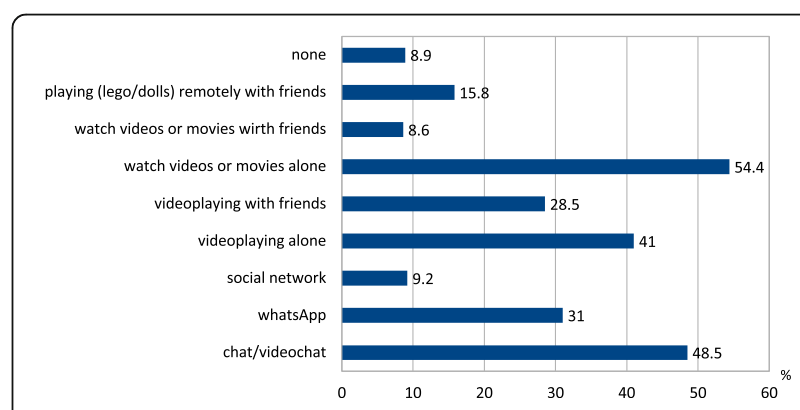

Fig. 1 Leisure activities performed by children in OC (6-10 years of age) group 


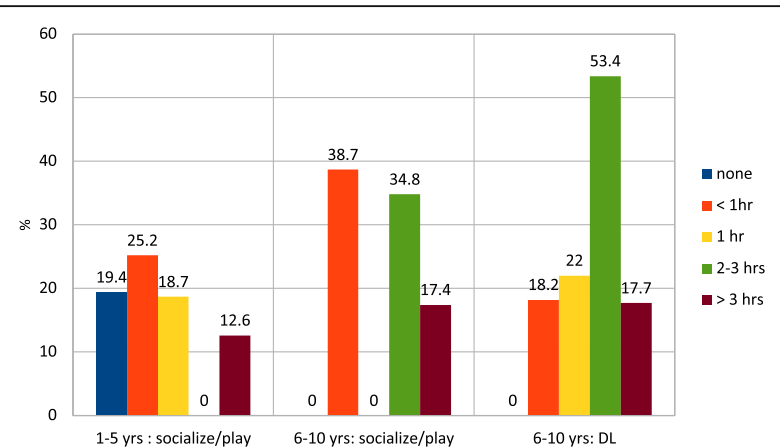

Fig. 2 Time (hours) spent using digital devices for socialize, play and distance learning (DL) in YC (1-5 years of age) and OC (6-10 years of age) group

electronic register or email, 43\% used a virtual classroom, 39\% recorded video lessons, and 14\% digital contents.

For leisure activities, socializing and play, half of subjects in the OC group used parents' devices, $24 \%$ a personal device, and both $18 \%$. The activities performed are reported in Fig. 1. The time spent using electronic devices for socialize, play and DL is illustrated in Fig. 2. An increase of time for TV watching was reported in 41 and $32 \%$ of $\mathrm{YC}$ and OC, respectively.

Finally, the results of the multiple logistic regression for sleep, attention and irritability disturbances in $\mathrm{OC}$ are given in Tables 2, 3 and 4, respectively. The results of

Table 2 Odds ratios (and confidence intervals) of sleep disturbances in children 6-10 years of age during the lockdown period

\begin{tabular}{lllll}
\hline & $\begin{array}{l}\text { Odds } \\
\text { ratio }\end{array}$ & $\begin{array}{l}\text { Lower } \\
\mathbf{9 5 \%} \mathrm{Cl}\end{array}$ & $\begin{array}{l}\text { Upper } \\
\mathbf{9 5 \%} \mathrm{Cl}\end{array}$ & $\begin{array}{l}\boldsymbol{p} \text { - } \\
\text { Value }\end{array}$ \\
\hline $\begin{array}{l}\text { Sex (male) } \\
\text { Number of siblings }\end{array}$ & 0.76 & 0.61 & 0.97 & 0.02 \\
1 & 1.11 & 0.82 & 1.50 & 0.48 \\
2 & 0.74 & 0.51 & 1.08 & 0.12 \\
3 & 0.98 & 0.60 & 1.61 & 0.93 \\
4 or more & 0.42 & 0.12 & 1.43 & 0.17
\end{tabular}

Relation between parents during lockdown

$\begin{array}{lllll}\text { Worsened } & 1.18 & 0.88 & 1.60 & 0.27 \\ \text { Improved } & 0.75 & 0.57 & 0.98 & 0.04\end{array}$

Remote work

$\begin{array}{lllll}\text { One parent } & 0.87 & 0.66 & 1.15 & 0.33 \\ \text { Both parents } & 0.51 & 0.38 & 0.69 & < \\ & & & & 0.0001 \\ \begin{array}{l}\text { Time spent for screentime } \\ \text { (hours/day) }\end{array} & 1.32 & 1.04 & 1.68 & 0.02 \\ \end{array}$

Time spent for watching television

\begin{tabular}{lllll} 
Decreased & 1.29 & 0.79 & 2.11 & 0.32 \\
Increased & 1.46 & 1.12 & 1.90 & 0.005 \\
\hline
\end{tabular}

Table 3 Odds ratios (and confidence intervals) of attention disturbances in children 6-10 years of age during the lockdown period

\begin{tabular}{lllll}
\hline & $\begin{array}{l}\text { Odds } \\
\text { ratio }\end{array}$ & $\begin{array}{l}\text { Lower } \\
\mathbf{9 5 \% ~ C l}\end{array}$ & $\begin{array}{l}\text { Upper } \\
\mathbf{9 5 \%} \mathrm{Cl}\end{array}$ & $\begin{array}{l}\boldsymbol{p} \text { - } \\
\text { Value }\end{array}$ \\
\hline Gender (male) & 0.78 & 0.61 & 0.99 & 0.04
\end{tabular}

Relation between parents during lockdown

\begin{tabular}{|c|c|c|c|}
\hline Worsened & 2.11 & 1.53 & 2.92 \\
\hline Improved & 0.87 & 0.65 & 1.15 \\
\hline \multicolumn{4}{|l|}{ Remote work } \\
\hline One parent & 1.16 & 0.87 & 1.57 \\
\hline Both parents & 0.82 & 0.60 & 1.13 \\
\hline ime spent for screentime & 1.25 & 0.97 & 1.61 \\
\hline
\end{tabular}
(hours/day)

Time spent for watching television

$\begin{array}{lllll}\text { Decreased } & 1.27 & 0.75 & 2.15 & 0.37 \\ \text { Increased } & 1.32 & 1.01 & 1.73 & 0.04\end{array}$

multiple logistic regression for sleep, attention, and moods disturbances are reported in Tables 5, 6 and 7 for YC, respectively.

\section{Discussion}

To our knowledge, this is the first large-scale Italian study assessing the effects of lockdown on daily life, behaviors, relationships, technological devices, and distance learning experience during the COVID-19 pandemic in children $1-10$ years of age.

This study highlights both negative and positive consequences of the lockdown period in children. Overall, it shows an increase in irritability, sleep and dietary habits alterations, attention disturbances and excessive use of digital technologies. However, an improvement in family relationships was also frequently reported.

In $\mathrm{OC}$ group, the male gender, the improvement of family relationships and remote working (by both parents) positively influenced sleep, emotional and behavioral disturbances. On the contrary, screen time and an increase in the time spent watching television negatively influenced sleep habit and attention. Finally, the worsening of family relationships was strongly associated with attention disturbances and irritability. In YC group, parents' remote working and presence of courtyard positively influenced the sleep, while worsened relation between parents was negatively associated with sleep problems. Overall, our data confirm the correlations between family relations, time spent for screen time and sleep $[14,15]$.

Improved relationships between parents and their children, and parents' remote working positively influenced mood disturbances. Similarly, attention disturbances 
Table 4 Odds ratios (and confidence intervals) of irritability disturbances in children 6-10 years of age during the lockdown period

\begin{tabular}{lllll}
\hline & Odds ratio & Lower 95\% Cl & Upper 95\% Cl & $\boldsymbol{p}$-Value \\
\hline Age (years) & 0.92 & 0.84 & 1.01 & 0.09
\end{tabular}

Relation between parents during lockdown

$\begin{array}{lllll}\text { Worsened } & 1.98 & 1.29 & 3.03 & 0.002 \\ \text { Improved } & 0.91 & 0.67 & 1.23 & 0.5\end{array}$

Relation between parents and the child during lockdown

\begin{tabular}{ccccc} 
Worsened & 7.86 & 4.83 & 12.8 & $<0.0001$ \\
Improved & 0.58 & 0.44 & 0.78 & 0.0002 \\
\hline
\end{tabular}

were associated with worsened relations between parents and children and by screen time over $2 \mathrm{~h}$.

The data on the role of relationship between parents and children during lockdown support the assumption that children serve as "emotional barometers" for their family and often reflect the level of stress of parents and caregivers [16]. In addition, these data further highlight the association between parental well-being and health of children [16, 17]. The most innovative aspect of this study that deserves further investigations is the possible positive role of parents' remote working on the wellbeing of the whole family.

This survey shows that digital technology has been widely used and likely played a crucial role not only for DL but also for social relationships. On the other hand, the literature points out that the use of digital technology for social relationships deserve a continuous monitoring to prevent an excessive use of such devices [18]. This issue is also supported by data previously published on the same group of children that highlighted the

Table 5 Odds ratios (and confidence intervals) of sleep disturbances in children 1-5 years of age during the lockdown period

\begin{tabular}{lllll}
\hline & Odds ratio & Lower 95\% Cl & Upper 95\% Cl & p-Value \\
\hline Age (years) & 0.86 & 0.79 & 0.95 & 0.003 \\
\multicolumn{5}{l}{ Relation between parents during lockdown } \\
Worsened & 1.54 & 1.12 & 2.11 & 0.008 \\
Improved & 1.05 & 0.77 & 1.42 & 0.8
\end{tabular}

Relation between parents and the child during lockdown

$\begin{array}{lllll}\text { Worsened } & 1.49 & 1.08 & 2.06 & 0.01 \\ \text { Improved } & 0.91 & 0.66 & 1.26 & 0.58\end{array}$

Remote work

\begin{tabular}{|c|c|c|c|c|}
\hline One parent & 0.64 & 0.47 & 0.86 & 0.003 \\
\hline Both parents & 0.60 & 0.44 & 0.83 & 0.002 \\
\hline \multicolumn{5}{|c|}{ resence of an external space in the house } \\
\hline Balcony & 0.57 & 0.35 & 0.94 & 0.03 \\
\hline Courtyard & 0.36 & 0.23 & 0.58 & $<0.000$ \\
\hline
\end{tabular}

Table 6 Odds ratios (and confidence intervals) of attention disturbances in children 1-5 years of age during the lockdown period

\begin{tabular}{lllll}
\hline & $\begin{array}{l}\text { Odds } \\
\text { ratio }\end{array}$ & $\begin{array}{l}\text { Lower } \\
\mathbf{9 5 \% ~ C l}\end{array}$ & $\begin{array}{l}\text { Upper } \\
\mathbf{9 5 \% ~ C l}\end{array}$ & $\begin{array}{l}\boldsymbol{p} \text { - } \\
\text { Value }\end{array}$ \\
\hline Age (years) & 1.69 & 1.52 & 1.90 & $<$ \\
& & & & 0.0001
\end{tabular}

Relation between parents during lockdown

$\begin{array}{lllll}\text { Worsened } & 1.30 & 0.93 & 1.82 & 0.1 \\ \text { Improved } & 0.72 & 0.52 & 1.00 & 0.05\end{array}$

Relation between parents and the child during lockdown

\begin{tabular}{lcccc} 
Worsened & 2.16 & 1.54 & 3.02 & $<$ \\
& & & & 0.0001 \\
Improved & 0.91 & 0.64 & 1.28 & 0.6 \\
$\begin{array}{l}\text { Use of a device for more } \\
\text { than 2 h per day }\end{array}$ & 1.42 & 1.04 & 1.94 & 0.03 \\
$\begin{array}{l}\text { Time spent for watching television } \\
\text { Decreased }\end{array}$ & & & \\
Increased & 0.73 & 0.29 & 1.87 & 0.5 \\
\hline
\end{tabular}

parental concern of addiction to devices especially in younger children [13].

Our findings on DL are comparable to those of previous studies conducted in other countries [19-21]. In one study performed in China in 2020 (an online survey given to children, parents, and teachers) the majority of responders reported that the home-schooling style was acceptable [20]. However, teachers were concerned that students' academic performance and interest would decline, and parents reported an increase in daily screen time and a decrease in outdoor activity. Negative effects of home-schooling were also described in another multicenter study performed in Europe. Most subjects

Table 7 Odds ratios (and confidence intervals) of moods disturbances in children 1-5 years of age during the lockdown period

\begin{tabular}{|c|c|c|c|c|}
\hline & Odds ratio & Lower $95 \% \mathrm{Cl}$ & Upper $95 \% \mathrm{Cl}$ & $p$-Value \\
\hline \multicolumn{5}{|c|}{ Relation between parents during lockdown } \\
\hline Worsened & 1.06 & 0.67 & 1.70 & 0.8 \\
\hline Improved & 0.67 & 0.46 & 0.97 & 0.03 \\
\hline \multicolumn{5}{|c|}{ Relation between parents and the child during lockdown } \\
\hline Worsened & 9.45 & 4.72 & 18.9 & $<0.0001$ \\
\hline Improved & 0.76 & 0.53 & 1.10 & 0.1 \\
\hline \multicolumn{5}{|l|}{ Remote work } \\
\hline One parent & 0.71 & 0.46 & 1.09 & 0.1 \\
\hline Both parents & 0.47 & 0.30 & 0.72 & 0.0005 \\
\hline \multicolumn{5}{|c|}{ Time spent for watching television } \\
\hline Decreased & 0.65 & 0.24 & 1.75 & 0.4 \\
\hline Increased & 1.51 & 0.57 & 3.96 & 0.4 \\
\hline
\end{tabular}


reported detrimental effects of distance learning both for themselves and their offspring, with insufficient support from schools and generally poor quality of teaching [21].

The results of this study could be a stimulus for further investigations to know if positive effects observed in the first lockdown persist after the resumption of schools with a situation of uncertainty and restrictions. Considering their importance on family attitudes and children development, family pediatricians might play a key-role to support such positive aspects [22].

In the future, policymakers should address efforts to support and reinforce the relationship within and between families and community services, particularly pediatricians and schools. In this perspective, it is important to early detect emotional distress both in children and parents and plan interdisciplinarybased support interventions.

The current study has many limitations, including the cross-sectional and single-region design. Moreover, we did not use validated measures and scales. The questionnaire did not consider other potentially influencing factors and the opinions of the children themselves [23]. Finally, information on socioeconomic status of the respondents was not available. On the other hand, the main strengths of this study include the rather large sample size and that it was conducted in Lombardy, a region with a high burden of SARS-CoV-2 infection during the first wave of SARS-CoV-2 infection both on children and adults [24, 25].

\section{Conclusions}

This study reports the most updated data on the effects of COVID-19 pandemic lockdown on Italian children between 1 and 10 years of age, with a focus on changes in daily life, behaviors, social relationships, digital technologies use and distance learning experience. The change of family relationships, parents' remote working and screen time were associated with sleep, emotional and behavioral modifications. These data show that pediatricians and health authorities should address efforts to support the relationships within families. Parents' remote working might also play an important, positive role on children health.

\section{Abbreviations \\ COVID-19: Coronavirus disease 2019; DL: Distance Learning; SICuPP- Lombardia: Società Italiana delle Cure Primarie Pediatriche Lombardia}

\section{Acknowledgments}

This study would not have been possible without the generous cooperation of pediatricians and of all the families who took part in the survey.

\section{Authors' contributions}

This study was a collaboration among all authors and each author gave a contribution in study design and data interpretation. All the author(s) read and approved the final manuscript.

\section{Funding}

The publication has been partially supported by a grant from Italian Ministry of Health (Ricerca corrente 2020).

\section{Availability of data and materials}

The datasets used and/or analysed during the current study are available from the corresponding author on reasonable request.

\section{Declarations}

\section{Ethics approval and consent to participate}

The study was conducted in compliance with all ethical research standards. All parents provide their consent to participate. The entire research process was monitored and approved by the University of Milano Bicocca, in keeping with the ethical standards required for all forms of research and inquiry.

\section{Consent for publication}

The collected data were used in an anonymous and aggregate form, in compliance with the EU General Data Protection Regulation n. 679/2016 (D.gls. n.196/2003 "Codice di Protezione in materia di dati personali" (modified by D.gls. n. 101 del 10.08.2018).

\section{Competing interests}

The authors declare that they have no competing interests.

\section{Author details}

${ }^{1}$ SICuPP-Lombardia: Società Italiana delle Cure Primarie Pediatriche Lombardia (Italian Primary Care Paediatrics Society-Lombardy), Milan, Italy. 'Fondazione IRCCS Ca' Granda - Ospedale Maggiore Policlinico, Pediatric Area, Via della Commenda 9, 20121 Milan, Italy. ${ }^{3}$ Department of Clinical Sciences and Community Health, University of Milan, Milan, Italy. ${ }^{4}$ Bambini Bicocca S.r.l., University of Milan-Bicocca, Milan, Italy. ${ }^{5}$ Department of Human Sciences for Education, University of Milan-Bicocca, Milan, Italy.

Received: 4 August 2021 Accepted: 15 September 2021

Published online: 11 October 2021

\section{References}

1. Jiao WY, Wang LN, Liu J, Fang SF, Jiao FY, Pettoello-Mantovani $M$, et al. Behavioral and emotional disorders in children during the COVID-19 epidemic. J Pediatr. 2020;221:264-6. https://doi.org/10.1016/j.jpeds.2020. 03.013.

2. Pierce $M$, Hope $H$, Ford T, Hatch S, Hotopf M, John A, et al. Mental health before and during the COVID-19 pandemic: a longitudinal probability sample survey of the UK population. Lancet Psychiatry. 2020;7(10):883-92. https://doi.org/10.1016/S2215-0366(20)30308-4.

3. Takahashi F, Honda H. Prevalence of clinical-level emotional/behavioral problems in schoolchildren during the coronavirus disease 2019 pandemic in Japan: a prospective cohort study. JCPP Adv. 2021;1:e12007.

4. Segre G, Campi R, Scarpellini F, Clavenna A, Zanetti M, Cartabia M, et al. Interviewing children: the impact of the COVID-19 quarantine on children's perceived psychological distress and changes in routine. BMC Pediatr. 2021; 21(1):1-11. https://doi.org/10.1186/s12887-021-02704-1.

5. Uccella S, De Grandis E, De Carli F, D'Apruzzo M, Siri L, Preiti D, et al. Impact of the COVID-19 outbreak on the behavior of families in Italy: a focus on children and adolescents. Front Public Heal. 2021;9:608358. https://doi.org/1 0.3389/fpubh.2021.608358.

6. López-Bueno R, López-Sánchez GF, Casajús JA, Calatayud J, Tully MA, Smith L. Potential health-related behaviors for pre-school and school-aged children during COVID-19 lockdown: a narrative review. Prev Med. 2021;143: 106349. https://doi.org/10.1016/j.ypmed.2020.106349.

7. Buzzi C, Tucci M, Ciprandi R, Brambilla I, Caimmi S, Ciprandi G, et al. The psycho-social effects of COVID-19 on Italian adolescents' attitudes and behaviors. Ital J Pediatr. 2020;46(1):4-10. https://doi.org/10.1186/s13052-02000833-4.

8. Gruppo di lavoro ISS Salute mentale ed emergenza COVID 19. Indicazioni ad interim per un appropriato sostegno della salute mentale nei minori di età durante la pandemia COVID-19. 2020.

9. Interim Guidance on Supporting the Emotional and Behavioral Health Needs of Children, Adolescents, and Families During the COVID-19 
Pandemic: Guidance for pediatricians on how to integrate emotional and behavioral health as part of standard care. Available from: https://services.aa p.org/en/pages/2019-novel-coronavirus-covid-19-infections/clinical-guida nce/interim-guidance-on-supporting-the-emotional-and-behavioral-healthneeds-of-children-adolescents-and-families-during-the-covid-19-pandemic/

10. Buonsenso D, Munblit D, Simpson FK. Clinical characteristics, activity levels and mental health problems in children with long COVID: a survey of 510 children. 2021; Available from: www.preprints.org

11. Pietrobelli A, Pecoraro L, Ferruzzi A, Heo M, Faith M, Zoller T, et al. Effects of COVID-19 lockdown on lifestyle behaviors in children with obesity living in Verona, Italy: A Longitudinal Study. Obesity. 2020;28(8):1382-5. https://doi. org/10.1002/oby.22861.

12. de Winter JP, de Winter D, Bollati V, Milani GP. A safe flight for children through COVID-19 disaster: keeping our mind open! Eur J Pediatr. 2020; 179(8):1175-7. https://doi.org/10.1007/s00431-020-03668-7.

13. Mantovani S, Bove C, Ferri P, Manzoni P, Cesa Bianchi A, Picca M. Children "under lockdown": voices, experiences, and resources during and after the COVID-19 emergency. Insights from a survey with children and families in the Lombardy region of Italy. Eur Early Child Educ Res J. 2021;29(1):35-50. https://doi.org/10.1080/1350293X.2021.1872673.

14. Öztürk M, Boran P, Ersu R, Peker Y. Possums-based parental education for infant sleep: cued care resulting in sustained breastfeeding. Eur J Pediatr. 2021;180(6):1769-76. https://doi.org/10.1007/s00431-021-03942-2.

15. Zhang Z, Adamo KB, Ogden N, Goldfield GS, Okely AD, Kuzik N, et al. Longitudinal correlates of sleep duration in young children. Sleep Med. 2021;78:128-34. https://doi.org/10.1016/.sleep.2020.12.023.

16. Reiss F, Meyrose AK, Otto C, Lampert T, Klasen F, Ravens-Sieberer U. Socioeconomic status, stressful life situations and mental health problems in children and adolescents: Results of the German BELLA cohort-study. PLoS One. 2019;14(3):e0213700.

17. Frigerio A, Rucci P, Goodman R, Ammaniti M, Carlet O, Cavolina P, et al. Prevalence and correlates of mental disorders among adolescents in Italy: the PrISMA study. Eur Child Adolesc Psychiatry. 2009;18(4):217-26. https:// doi.org/10.1007/s00787-008-0720-x.

18. Balbinot V, Toffol G, Tamburlini G. Tecnologie digitali e bambini: un'indagine sul loro utilizzo nei primi anni di vita. Med e Bambino. 2016;35:631-6.

19. Schneider SL, Council ML. Distance learning in the era of COVID-19. Arch Dermatol Res. 2020;313:389-90.

20. Zhao Y, Guo Y, Xiao Y, Zhu R, Sun W, Huang W, et al. The effects of online homeschooling on children, parents, and teachers of grades 1-9 during the COVID-19 pandemic. Med Sci Monit. 2020;26:1-10. https://doi.org/10.12659/ MSM.925591.

21. Thorell LB, Skoglund $C$, de la Peña AG, Baeyens D, Fuermaier ABM, Groom MJ, et al. Parental experiences of homeschooling during the COVID-19 pandemic: differences between seven European countries and between children with and without mental health conditions. Eur Child Adolesc Psychiatry. 2021;0123456789). Epub ahead of print. https://doi.org/10.1007/ s00787-020-01706-1.

22. Brambilla P, Giussani M, Picca M, Bottaro G, Buzzetti R, Milani GP, et al. Do the opinions of pediatricians influence their recommendations on complementary feeding? Preliminary results. Eur J Pediatr. 2020;179(4):62734. https://doi.org/10.1007/s00431-019-03548-9.

23. Mastorci F, Piaggi P, Bastiani L, Trivellini G, Doveri C, Casu A, et al. The impact of menarche on health-related quality of life in a sample of Italian adolescents: evidence from school-based AVATAR project. Eur J Pediatr. 2020;179(6):973-8. https://doi.org/10.1007/s00431-020-03594-8.

24. Milani GP, Bottino I, Rocchi A, Marchisio P, Elli S, Agostoni C, et al. Frequency of children vs adults carrying severe acute respiratory syndrome coronavirus 2 asymptomatically. JAMA Pediatr. 2021;175(2):193-4. https:// doi.org/10.1001/jamapediatrics.2020.3595.

25. Milani GP, Marchisio P, Rocchi A, Bertolozzi G, Furlan L, La Vecchia A, et al. Frequency of asymptomatic carriers of SARS-CoV-2 among children and adults after school reopening. Ital J Pediatr. 2021;47(1):1-4. https://doi.org/1 0.1186/s13052-021-01016-5.

\section{Publisher's Note}

Springer Nature remains neutral with regard to jurisdictional claims in published maps and institutional affiliations.

\section{Ready to submit your research? Choose BMC and benefit from}

- fast, convenient online submission

- thorough peer review by experienced researchers in your field

- rapid publication on acceptance

- support for research data, including large and complex data types

- gold Open Access which fosters wider collaboration and increased citations

- maximum visibility for your research: over $100 \mathrm{M}$ website views per year

At $\mathrm{BMC}$, research is always in progress.

Learn more biomedcentral.com/submissions 